\title{
Patristics and Sociolinguistics
}

\author{
Cyril Hovorun \\ Postdoctoral Research Fellow, Loyola Marymount University, \\ Los Angeles, CA, USA \\ hovorun@gmail.com
}

\begin{abstract}
The paper suggests a new hermeneutical take on receptive patristics. Receptive patristics means here the ways in which patristic texts are perceived in the community of patristic scholars and in ecclesiastical communities. The perceptions of the patristic materials that these two kinds of communities demonstrate are not always convergent. Their divergence can be explained on the basis of the distinction between normative linguistics and sociolinguistics. Ecclesiastical communities tend to treat the language of the Fathers and Mothers of the church in coherence with the way in which the proponents of normative linguistics treat the phenomenon of language. Patristic scholars, in contrast, usually treat them along the line of sociolinguistics. The approach to the language, which is applied by sociolinguistics, if adopted by ecclesiastical communities, could lead to a better understanding between them. It could foster the ecumenical rapprochement between confessional traditions, especially if they are based on patristic identities, such as in the case of Byzantine and Oriental churches. The academic method of sociolinguistics, thus, can be applied to the ecumenical studies and can positively contribute to practical ecumenism.
\end{abstract}

\section{Keywords}

sociolinguistics - linguistics - sociology of language - speech community - theological language

Patristic languages can be understood in two senses. ${ }^{1}$ On the one hand, they are languages per se, in which patristic texts have been written: Greek, Latin,

1 This manuscript is an extended version of the paper presented at the Asia-Pacific Early Christian Studies Society 12th Annual Conference in Okayama, Japan, in September 2018. 
Coptic, Syriac, Armenian, Georgian, Ethiopian, etc. On the other hand, they are languages in a broader sense; they include theological phrases and formulas translatable in multiple languages. The patristic languages in the latter sense are based on what we now call discourse. When we apply the term discourse to the patristic languages, we act anachronistically, because this postmodernist term is hardly applicable to the premodern era, when most patristic texts were written. Nevertheless, this term can be helpful in explaining the point of this paper.

Just as peoples, for example, in Syria and Egypt spoke their own languages (Syriac and Coptic), they developed their distinct theological dialects and languages. Languages in the proper sense (Syriac, Coptic, etc.) certainly contributed to the formation of theological languages. At the same time, it occurred quite often that the same theological language could be expressed in different languages per se. For instance, Greek and Latin converged in expressing the Chalcedonian theological language. They diverged, however, when later they were used in articulating the procession of the Holy Spirit and the distinction between the essence and energeiai in the Holy Trinity, or in discussions on primacy in the church.

The point of this paper is that distinctions between linguistics and sociolinguistics are applicable not only to languages in the proper sense, but also to theological languages. Particularly useful in the analysis of both kinds of patristic languages can be a branch of sociolinguistics know as Critical discourse analysis (CDA). ${ }^{2}$ It deals with complex textual structures, larger than sentence. ${ }^{3}$ In application to the patristic languages, CDA can deal with variability of theological formulas and phrases.

Sociolinguistics is based on the assumption that languages and social structures are intrinsically connected with one another. This assumption was made first by Japanese scholars in the 1930s. The term sociolinguistics as such was coined in 1939 by a Cambridge anthropologist Thomas Hodson. The discipline of sociolinguistics flourished after the World War II. Haver Currie in $195^{2}$ defined it as a field of cross-study between sociology and language. In some studies, sociolinguistics has been differentiated from the sociology of language. The former has been identified as micro-sociolinguistics, while the latter, as macro-sociolinguistics. Richard Hudson defined micro-sociolinguistics as the study of language in relation to society, while macro-sociolinguistics, as the study of society in relation to language. ${ }^{4}$ For Florian Coulmas,

2 See Sociolinguistics: Theoretical Debates, ed. N. Coupland, Cambridge, 2016, p. 10.

3 See M. Garner, "Techniques of Analysis," in: The Routledge Companion to Sociolinguistics, ed.

C. Llamas, L. Mullany, P. Stockwell, London-New York, 2015, pp. 41-47.

4 R. Hudson, Sociolinguistics, Cambridge, 1996, pp. 4-5. 
Micro-sociolinguistics investigates how social structure influences the way people talk and how language varieties and patterns of use correlate with social attributes such as class, sex, and age. Macro-sociolinguistics, on the other hand, studies what societies do with their languages, that is, attitudes and attachments that account for the functional distribution of speech forms in society, language shift, maintenance, and replacement, the delimitation and interaction of speech communities. ${ }^{5}$

The "macro-" aspect of sociolinguistics is more appropriate for our study here. It will help us better to analyze the reception of patristic languages by both scholarly and ecclesiastical communities. Therefore, while speaking about sociolinguistics, we imply primarily its social impact, which is studied by macrosociolinguistics.

The bottom line of both micro- and macro-sociolinguistics is that the linguistic structures influence social structures and in return get influenced by the latter. ${ }^{6}$ Particularly important for us here is how linguistic structures influence or even determine social structures. This influence is studied as "linguistic determinism" or the "linguistic relativity hypothesis." It was introduced by the German anthropologist Edward Sapir ${ }^{7}$ and significantly improved by his student Benjamin Lee Whorf; it is known as the "Sapir-Whorf hypothesis" or the "Whorfian hypothesis." It was recently updated by Guy Deutscher.8 The hypothesis states:

The social categories we create and how we perceive events and actions are constrained by the language we speak. Different speakers will therefore experience the world differently insofar as the languages they speak differ structurally. ${ }^{9}$

In application to the patristic texts, this would imply the common wisdom that theological differences were often determined by the languages, in which they were expressed. For instance, the difference between the Chalcedonian and non-Chalcedonian theologies is often explained by the fact that the former was articulated mostly in Greek, while the latter, mostly in Syriac, Coptic, and Armenian.

5 The Handbook of Sociolinguistics, ed. F. Coulmas, Oxford, 1997, p. 2.

6 R. Wardhaugh, J. Fuller, An Introduction to Sociolinguistics, New York, 2015, p. 42.

7 E. Sapir, Language: An Introduction to the Study of Speech, New York, 1921.

8 G. Deutscher, Through the Language Glass: Why the World Looks Different in Other Languages, New York, 2010.

9 Wardhaugh and Fuller, An Introduction to Sociolinguistics, p. 11. 
Sociolinguistics can provide a more nuanced take on this common wisdom. It takes the normativity of language differently from the way that classical linguistics treats the phenomenon of language. Classical linguistics tends to see language as an ideal construct with singular normativity. This normativity is often imposed upon speakers, who are thus supposed to be ideal. Sociolinguistics, in contrast, sees its speakers not as ideal, but as real bearers of language. They speak not a high normative language, but a language with a high degree of variativity and flexibility.

As Steven Pinker noticed, "linguists often theorize about a language as if it were the fixed protocol of a homogeneous community of idealized speakers, like the physicist's frictionless plane and ideal gas." ${ }^{10}$ Sociolinguists, in contrast, study language as intrinsically linked to social realities. According to Jack Chambers, "Sociolinguistics is the study of the social uses of language, and the most productive studies... have emanated from determining the social evaluation of linguistic variants."11

These two approaches have been elaborated by two prominent scholars of language: Noam Chomsky and William Labov. In the 196os, Chomsky argued that there is no much relation between language and society. He effectively developed an asocial linguistics. For him,

Linguistic theory is concerned primarily with an ideal speaker - listener, in a completely homogeneous speech-community, who knows its language perfectly and is unaffected by such grammatically irrelevant conditions as memory limitations, distractions, shifts of attention and interest, and errors (random or characteristic) in applying his knowledge of the language in actual performance. ${ }^{12}$

In contrast to Chomsky, William Labov believed that languages should be studied in their variativity and applicability to real usage. In the same period of time, when Chomsky developed his normative linguistics, Labov conducted a field study of language's variability on the island of Martha's Vineyard in New England. This has become the foundational field study in sociolinguistics. Labov researched how the locals in different locations of the island used some vowels and consonants. On the basis of this linguistic analysis, he made socio-

\footnotetext{
10 S. Pinker, The Stuff of Thought, New York, 2007, p. 74.

11 J.K. Chambers, P. Trudgill, N. Schilling-Estes, The Handbook of Language Variation and Change, Malden, MA, 2002, p. 3 .

12 N. Chomsky, Aspects of the Theory of Syntax, Cambridge, MA, 1965, pp. 3-4.
} 
logical conclusions about the attitude of the locals to their homeland and to the holiday makers from the mainland. ${ }^{13}$

For Chomsky, language is prescriptive, while for Labov, it is descriptive. The distinction between their approaches to language gives to the students of patristics an important hermeneutical key. Indeed, the language of the Fathers and Mothers of the church (language understood in the broader sense of a theological discourse) can be perceived as either normative or variable. The former perception is pertinent to the ecclesiastical communities that rely on it. The normativity of this language is highly influential in shaping identity and ethos of these communities. The impact of the patristic languages on ecclesiastical communities is higher than the impact of conventional languages upon speech communities. This is because patristic languages are usually perceived as sacred, while conventional languages are usually perceived as profane.

While the ecclesiastical communities, for whom patristic languages feature ultimate normativity and authority, perceive them in Chomsky's way, the perception of the patristic languages in the patristic studies is more Labovian. Patristic scholars treat patristic languages in their variety and variability, as real and not ideal phenomena. Therefore, the assumptions of the patristic studies about patristic languages are closer to the assumption of sociolinguistics than of linguistics as such.

At the same time, patristics tends to focus on individuals and their texts rather than on communities, which underpin and appropriate these texts. This is a major difference of modern patristic scholarship from sociolinguistics, which focuses on what it calls "speech community."14 The focusing of sociolinguistics on speech communities was first accentuated by William Labov, ${ }^{15}$ for whom "the behavior of the individual cannot be understood without a knowledge of the larger community that he or she belongs to."16 As John Gumperz adds to this:

Modern sociolinguistics had its beginning with the recognition that anyone seeking to relate linguistic to social and political forces must take the speech community, seen as a group of communicating individuals, as the analytical starting-point rather than focusing on languages or dialects as such. Speech communities, broadly conceived, can be regarded as collectivities of social networks. Networks come in different types. Of

13 W. Labov, Sociolinguistic Patterns, Philadelphia, 1972.

14 See L. Mullany, "Speech Communities," in: The Routledge Companion to Sociolinguistics, pp. 84-91.

15 Labov, Sociolinguistic Patterns, pp. 120-121.

16 W. Labov, Principles of Linguistic Change, vol. 3, Malden, MA, 2010, p. 208. 
crucial transmission is the primary network of socialization, into which one is recruited by kinship, and from which are recruited friends and often neighbors and co-workers. ${ }^{17}$

Modern patristic studies still miss the communal dimension, which remains strong in the ecclesiastical communities receiving patristic texts. Proper attention paid to this dimension can reconcile the Chomsky's and Labovian approaches to the patristic languages. Seeing the patristic texts from the perspective of speech communities can also explain the divisions between these communities and suggest ways towards their eventual reconciliation.

The speech communities from the perspective of patristic studies would be the ecclesiastical communities of believers who have chosen to speak the theological language of a certain Father or of the group of church Fathers. Thus, for example, the community in western Syria in the sixth century chose to speak the language of Severus of Antioch and his confederates, who in turn modified the theological language of Cyril of Alexandria. This theological language was originally articulated in Greek. The speech community that adopted it, however, soon rendered it to its own language, Syriac. The Syriac language of the community, on the one hand, modified the original theological language, which had been articulated in Greek. On the other hand, the same theological language, which stems from Cyril of Alexandria and Severus of Antioch, consolidated Syriac and Coptic speaking communities. The speech community, which spoke the same Syriac language, was thus broadened and included the Coptic speech community, after both of them had adopted the common theological language.

Another example could be the theological language of Augustine, which became appropriated as the main theological language in the Latin-speaking West. When after the Reformation the Western theological literature switched from Latin to vernacular languages, the Augustinian theological language was rendered to German, French, English, and other modern languages. It was also modified by numerous interpreters and theologians who followed the Augustinian line. Probably the most famous of them was Thomas Aquinas. Sometimes the later editions of a particular theological language became quite distant from its source. Nevertheless, the original Augustinian language constitutes a foundation for most posterior theological languages that have developed in the West. It keeps close to one another even groups, which turned to different confessions. Thus, the bottom line of Catholic, Protestant, Reformed,

17 J. Gumperz, "Introduction to The Social Matrix: Culture, Praxis, and Discourse," in: Rethinking Linguistic Relativity, ed. J. Gumperz, S. Levinson, Cambridge, 1996, p. 362. 
and Anglican theological languages remains Augustinian. At the same time, the Augustinian language preserves a certain distance between Western and Eastern Christianities. In my opinion, the Augustinian theology is completely appropriate for the East, but not every easterner would think so as well.

Many eastern theologians recently began speaking the theological language of Maximus the Confessor. Maximian lexemes and discourses, such as "logoi," "way of existence," "existence according and against nature," etc., turned to a sort of lingua franca of the modern Orthodox theology. However, sometimes the modern usage of Maximus's theological language is quite different from Maximus himself. For instance, Orthodox followers of personalism tend to ascribe to Maximus the modern personalistic understanding of the term "hypostasis." From the perspective of normative linguistics, such usage would be wrong. However, sociolinguistics would accept it as a case of variability of a theological language. Also the fact that such usage has been appropriated by a speech community (of Orthodox theologians), would provide an additional argument in favor of the personalistic reading of Maximus's theological language. The only problem with this reading is that it takes itself as a normative expression of Maximus's ideas. In other words, this approach to the theological language of Maximus still goes along the lines of normative linguistics, and not of variable sociolinguistics: it prescribes and not describes how Maximus should be read.

According to Muriel Saville-Troike, a criterion for a speech community is "that some significant dimension of experience has to be shared."18 Members of ecclesiastical communities communicate to one another by the means of shared theological languages their experience. The experience of a community can be of different sorts. Sometimes the reason why a community embarks on a particular theological language is that the Father who has uttered it comes from the same milieu. He might have also expressed local concerns, theological as well as social and political. In the period of Late Antiquity and Middle Ages, people often spoke politics in the language of theology. Therefore, the experiences that the speech communities shared through theological languages were mixed. On the one hand, they were spiritual and Christian. On the other hand, they were social and political. For instance, the group of Syrians in the fifth-sixth centuries adopted the language of anti-Chalcedonian theologians not only because this language expressed their shared experience of divinization of human nature through asceticism, but also because of their

18 M. Saville-Troike, The Ethnography of Communication: an Introduction, Malden, MA, 2009, p. 15 . 
common bitterness about imperial policies of Constantinople. The council of Chalcedon, to them, embodied exactly these policies. As a result, local population voiced out their political protests by rejecting the council.

In sociolinguistics, speech communities are sometimes called "communities of practice." According to Penelope Eckert and Sally McConnell-Ginet, these communities share "ways of doing things, ways of talking, beliefs, values, power relations - in short, practices." ${ }^{\text {19 }}$ Religious communities of practice express their ways of beliefs and values primarily through liturgical practices. In liturgy, the original theological languages of the Fathers and Mothers of the church, become appropriated by the community and turn to community's own languages. A theological language thus transforms to a shared norm. Shared norms have become a subject of meticulous investigation by sociolinguists. According to William Labov, speech communities are defined by shared norms:

The speech community is not defined by any marked agreement in the use of language elements, so much as by participation in a set of shared norms; these norms may be observed in overt types of evaluative behavior, and by the uniformity of abstract patterns of variation which are invariant in respect to particular levels of usage. ${ }^{20}$

In application to our topic this means that religious communities uphold their integrity and distinctiveness by participation in liturgy and other religious practices, which are based on theological languages received as normative. In other words, a theological language, which is rendered through liturgy as a shared language of community, turns to an unquestionable norm and ceases to be a possible variant of the normativity. As a result, it excludes other theological languages as competing with and not adding to their own adopted language. A community proclaims their language the only orthodox. This may lead it astray from other communities, which have adopted different languages.

Such an exclusivist attitude to community's own theological language as the only legitimate expression of Orthodoxy, in my judgement, was one of the reasons of the global schisms in Christianity. This was particularly the reason of the split that occurred in the eastern church after the council of

19 P. Eckert, S. McConnell-Ginet, "Think practically and look locally: language and gender as community-based practice," in: Annual Review of Anthropology, 21 (1992), p. 464.

20

Labov, Sociolinguistic Patterns, pp. 120-121. 
Chalcedon. Then what we now call Byzantine and Oriental groups embarked each on its own reception of the theological language of Cyril of Alexandria, and proclaimed it own shared language the only possible one. These communities tended to perceive their shared theological languages through the prism of linguistic normativity, and not through sociolinguistic variativity. If they perceived theological languages as modern sociolinguists do, probably they would not have to split from the groups that spoke other theological languages.

Instead, they transformed their languages to identities. Anthropologists would argue that this is a natural process for any people, when the language they speak becomes their identity. A nuance should be added to this common wisdom, which has been discussed earlier in the paper. Not only the language in the proper sense, that is Syriac or Coptic, contributed to the identity of Syrians or Copts, but also the theological languages they had adopted from their Fathers.

A theological language, which has turned to identity, can go quite astray from its original intention. The modern Byzantine-Oriental ecumenical dialogue is an illustration of how this can happen. The two sides of the dialogue have agreed that the original theologies, which underpin Byzantine and Oriental churches, did not significantly differ in what they meant regarding the incarnation of the Logos. Their differences were not semantical, but linguistic. Nevertheless, such a conclusion of the dialogue did not help the two groups to reconcile. The reason is because the original differences in theological languages have developed to identities. Now it is not enough anymore to reconcile theological languages. Without deconstruction or overriding of identities the theological reconciliation seems to be impossible.

Sociolinguistics gives us a clue how to approach theological languages elaborated by individual Fathers and Mothers of the church, and then received by communities. For the patristic studies, it confirms the approach of these studies to consider patristic texts not only through the lenses of normativity, but also as variables. It also suggests that patrologists should pay more attention to the communal perception and rendition of the patristic texts. At the same time, sociolinguistics explains how the way, in which the word of the Fathers and Mothers was received by communities and implemented in the policies of the church, has caused schisms and other tensions between large regional groups. These groups often tended to receive variables in the patristic texts as norms. They treated theological languages articulated by the Fathers and Mothers as ideal constructs instilled by God, and thus were unable to admit variabilities in it.

Some ecclesiastical splits could be avoided in the past, if methods of sociolinguistics were applied to theological languages. The still existent splits can be 
overridden if sociolinguistics is applied in the ecumenical dialogues. At the same time, sociolinguistics cannot explain and heal all divides among the Christian groups that rely on their theological languages. Its application to theology is limited, because some ancient theological texts differed not only in their wording, but in their meaning as well. When it comes to differences in meaning, sociolinguistics reaches its limits. 